\title{
Formulation of Rice Based Low Cost Balanced, Nutritious and Safe Diet for the Malnourished Street Children in Capital City Dhaka
}

\author{
Saima Jahan ${ }^{1}$, Sultan Abu Saleh Mahmud ${ }^{2}$, Iftekharul Huq ${ }^{3}$, Md \\ Mariful Islam ${ }^{2}$, Md Mohsin ${ }^{4}$, Md Sakil Ahamed ${ }^{5}$, Anika Antara \\ Siddiqquee $^{6}$, Zannatul Sanzida ${ }^{7}$, Habibul Bari Shozib ${ }^{2 *}$ and \\ Muhammad Ali Siddiquee ${ }^{2}$ \\ ${ }^{1}$ Mathemetical and Physical Sciences Department, East West University, Aftab \\ Nagar, Dhaka, Bangladesh \\ ${ }^{2}$ Grain Quality and Nutrition, Division, Bangladesh Rice Research Institute, Gazipur, \\ Bangladesh \\ ${ }^{3}$ Department of Economics, East West University, Aftab Nagar, Dhaka, Bangladesh \\ ${ }^{4}$ University of Development Alternative, Dhanmondi, Dhaka, Bangladesh \\ ${ }^{5}$ Department of Nutrition and Food Technology, Jashore University of Science and \\ Technology, Jashore, Bangladesh \\ ${ }^{6}$ Department of Biochemistry and Molecular Biology, Tejgoan College, Farmgate, \\ Dhaka, Bangladesh \\ ${ }^{7}$ Department of Computer Science and Engineering, Shanto-Mariam University of \\ Creative Technology, Uttara, Dhaka, Bangladesh
}

*Corresponding Author: Habibul Bari Shozib, Grain Quality and Nutrition, Division, Bangladesh Rice Research Institute, Bangladesh.

\author{
Received: May 11, 2021 \\ Published: June 30, 2021 \\ (C) All rights are reserved by Habibul Bari \\ Shozib., et al.
}

\begin{abstract}
A total of 384 street children were subjected to study a baseline survey aged from 4 to 12 years old in Capital City, Dhaka. The sample size was fixed by addressing Cochran equation. Among the respondents $63 \%$ were male and $37 \%$ were female from street children population of 384 . Survey took place at 20 different hot spots covering both Dhaka city north and south. We have observed the recommended dietary intake per day from 4 years to 12 years old male boys and found 27 to $59 \%$ deficiency in our male population samples of 243. Similarly, we also observed the recommended dietary intake per day from 4 years to 12 years old female girls and found 28 to 56\% deficiency in our female population samples of 141 . Since our Energy Dense Rice Cake (EDRC) has a potential of providing $500 \mathrm{kcal}$ energy per 100g serving so, we could predict that incorporating our improved rice-based product once a day along with their daily regular intake, it will able to mitigate nutritional gap by 64 to $100 \%$ for street boys and noticeably 70 to $100 \%$ for girls. We have prepared Energy Dense Rice Biscuit (EDRB, 3.6\% moisture, $515 \mathrm{kcal}$ per 100g of serving) and EDRC (5.0\% moisture, $500 \mathrm{kcal}$ per 100g of serving). EDRC was found prepared than EDRB in impact study when the respondents were given choice of rice-based bakery items intake for four months long period. Finally, a total of 32 respondents were took part in a four months period impact study on EDRC from street children population. All anthropometric and biochemical data such as CBC (Complete Blood Count), Hemoglobin, CRP, Prealbumin etc. were collected at both the starting (Day 0) and the end time (Day 120) of the impact survey of selected 32 respondents. Respondents were given $100 \mathrm{~g}$ serving of EDRC every day (rice cake) to 32 street children samples for 4 months period along with their normal food intake. Our data revealed that malnutrition related parameters specially CRP (decreased) and Prealbumin (Increased) are significantly improved during four months supplementary intake of extra 500 kcal per 100 g serving of EDRC in tested street children's samples which resembles the possible impact of EDRC on street children. Rice-based bakery products specially EDRB and EDRC can potentially be used in school feeding nutritional program and disaster management in Bangladesh.
\end{abstract}

Keywords: Energy Dense Rice Biscuit; Impact Study; Baseline Survey; Prealbumin; Formulated Food 


\section{Abbreviations}

EDRB: Energy Dense Rice Biscuit; EDRC: Energy Dense Rice Cake; ED: Energy Density; AAC: Apparent Amylose Content; GT: Gelatinization Temperature; OAC: Oil Absorption Capacity; WAC: Water Absorption Capacity

\section{Introduction}

In a street children consortium on promoting and protecting the rights of street children at Colombo, Srilanka back in 2001, Aparajeyo Bangladesh, for the first time bring the statistics that the estimated number of street children was 445226 in Bangladesh of which $75 \%$ were in Dhaka city and frequency were $53 \%$ boys and $47 \%$ girls [1]. Bangladesh Institute of Development Studies (BIDS) had reported in December 2004, a total number of street children in Bangladesh was 6, 74,178 [2]. In 2015, according to BIDS, the number becomes 1.5 million and it will reach to 1.56 million in 2024 [3]. Rural-urban migration is one of the major reasons of the exposure of the street children to the vulnerabilities. Considering the increasing trend of street children and diversity of the vulnerabilities, it is very much necessary to take proper and effective steps to protect the children from all types of violations, to ensure their basic necessities properly, to ensure their well growth and development. The given situation clearly reveals that there are no comprehensive and reliable statistics available on the actual numbers, living conditions, needs and interests of children living on the streets. But the fact is street children constitute one of the most vulnerable and marginal groups in Bangladesh. Hakim, et. al., 2016 in a study on health and nutritional condition of street children of Dhaka City revealed that about $65 \%$ street children are underweight and $22.5 \%$ children eat only two times in a day [4]. Masud Ahmed, 2011 conducted a population-based survey on lives and livelihoods on the streets of Dhaka City and his data revealed that housing, food, and lack of jobs are the three most common problems for which street people are commonly sought assistance [5]. Although there are several reports, case studies, surveys are available on street children of Bangladesh but very little information are available regarding food formulation especially for their nutritional requirement to address malnutrition. Our aim is to intervention at this point to make a concrete step to eradicate malnutrition with formulated rice-based food items. Since rice is an important source of energy, hypoallergenic, easily digested, providing protein with higher nutritional quality and has versatile functional nutraceutical properties [6] so, rice based low cost balanced, nutritious and safe diet formulation will able to address malnutrition related problems of the vulnerable section of our population especially urban street children. Among cereals, rice do not have gluten protein. Since gluten protein of wheat and maize cereals produce hypersensitivity reaction to human and we do not have multiple opinions other than consuming rice only so, rice-based food items such as rice cookies, rice ball, rice cake, rice noodles can be formulated at lower cost but higher nutritious value. We were aimed to formulate low cost and nutritionally balanced rice-based food items from nutritionally enriched selected brown and pre-germinated brown rice varieties. Finally, we had a plan to operate a volunteer promotion scheme of rice-based food items with multiple options for the malnourished children in urban city Dhaka. The small amount of quality rice-based products intake will reduce the consumption of rice intake gradually in Bangladesh. Street children problem in Bangladesh are social phenomena which also be given importance to enhance social and economic justice and equity. Our population target is children at age of 4 to 12 years and their daily recommended dietary intake (RDI in kcal of energy) requirements of boys and girls (from 4 years to 12 yrs. of age) ranges from 1303-2200 and $1202-2070 \mathrm{kcal} /$ day according to FAO for Bangladeshi population $[7,8]$. Rice based formulated diets for street children with moderate to acute malnutrition must have some important characteristics including high content of micronutrients, especially growth (type II) nutrients, high energy density, adequate high protein and fat content, low content of antinutrients, low risk of contamination, acceptable taste and texture, culturally acceptable, easy to prepare, affordable and available. We had tried to formulate our rice-based products with several ingredients including rice, egg, rice bran oil (RBO), salt, sugar etc. We had to focus on energy density of formulated food. If the energy density is too low, the food becomes too bulky, and the children will not be able to eat adequate amounts. We have a target to formulate food which will supplement at least $30 \%$ of total energy requirement by one meal solution and the formulated food should be high energy density (ED) food. Energy density is the ratio of energy per weight of food. The energy density is most important for children with wasting, as they have an increased energy need for catch-up growth. The most important factor influencing energy density is the fat content, as the ED of fat (9 $\mathrm{kcal} / \mathrm{g}$ ) according to the Atwater factors is more than double that of protein and carbohydrate (4 kcal/g). Another important factor is the water content. Since our target population is $4-12$ years old street children, so they might need more required energy and we propose to formulate rice-based food meeting energy density (ED) ranges from 4.5 - 5.5 for single dose meal. Our objectives of the study were I. Baseline survey on street children in Capital City Dhaka to understand the required calorie gap, II. Formulation of ricebased energy dense bakery food items and III. Impact evaluation study on energy dense rice biscuit (EDRB) food on street children.

\section{Materials and Methods}

Baseline survey on street children in capital city Dhaka

Street children are the vulnerable group of children coming to fight to gild the streets for their habitual abode and livelihood drifted into a nomadic life. These children are generally malnour- 
ished due to their deprivation on health and improved nutrition. Our plan was to nourished children from malnourished. To plan a need-based information is essential on their dietary pattern of street children. A baseline survey was done on 384 samples of the target population (street children in Dhaka City) to fill in this knowledge gap.

\section{Study areas}

A total of 20 study areas including all previously reported hot spot areas of street children in Dhaka City were accounted for conducting the baseline survey such as Shahbagh (Poribagh and shishu park area), Ramna (Dhaka University promises), Karwan Bazar, Kamlapur (Rail station area), Tejgoan (Industrial area), Agargoan (IDB Bhabon to Shamoli shishumela), Azimpur (Newmarket and graveyard), Baily road area, Shadorghat (Terminal area), Gulistan (Stadium area), Syedabad (Bus station area), Khilgoan (nearby Flyover area), Muhammadpur (Market and bus stand area), Mohakhali (Tangail bus stand to ICDDRB area), Mirpur 2 (Stadium area), Gabtoli (Bus station area to technicalmore), Uttara (Jasimuddin to house building area), Gulshan (circle 1 to circle 2 area), Moddo Badda (link road area), Rampura (Aftabnagor and Bonosri area).

\section{Target population}

Since street children are the most vulnerable group of children coming to fight to gild the streets for their habitual abode and livelihood drifted into a nomadic life. These children are generally malnourished due to their deprivation on health and improved nutrition. Our target population is both boys and girls of age from 4-12 years old street children.

Sampling and sample size

We have interviewed 384 street children from above mentioned 20 hot spots. Using Cochran Equation, we find the sample size:

$$
\text { Sample size }=\frac{z^{2} P(1-P)}{E^{2}}
$$

The value of $\mathrm{Z}$ is found in statistical tables which is contain the area under the normal curve. $Z=1.96$ for $95 \%$ level of confidence. $\mathrm{P}$ is the estimated proportion of an attribute that is present in the population.

$$
E^{2} \text { is the desired level of precision. }
$$

$$
\text { Sample size }=\frac{1.96^{2} \times 0.5 \times(1-0.5)}{0.05^{2}}=384.16 \cong 384
$$

\section{Development of tools}

A semi-structured questionnaire was developed to collect data through face-to-face interview with the respondents. The ques- tionnaires were pre-tested in areas outside our sample and were revised on the basis of feedback received from field-testing. The quantitative questionnaires mainly covered diverse information of study respondents such as socioeconomic and demographic characteristics, current living conditions and livelihood activities, morbidity and health-seeking behavior, dietary intake pattern, and education and drug uses, and anthropometrical measurement such as body weight and height, BMI, waist and hip circumferences ratio, mid-arm circumference. Since we were aimed to focus mainly in daily energy intake of street children in our baseline survey so we had considered their Calorie information for this paper only.

\section{The survey}

An instruction manual explaining the key terms in the questionnaire were developed and given to the enumerators. On the day of interview, the team identified the first respondent according to the definition of street dwelling child population and criteria for selection. The study included only those who will show interests on volunteer basis. Verbal consent will be taken before starting the interview. The field activities were supervised by the authors. Quality controls were measured accordingly. Before launching the actual study, all the techniques and tools were tested and modified under pre-testing. Enumerators were given extensive training, both in the classroom and in the field setting until the researchers were convinced about their abilities in collecting and managing data effectively and consistently. A field guideline detailing the definitions used, identification of prospective respondents, the steps to be followed during data collection, and trouble-shooting measures will be prepared for the data collectors. Effective and supportive supervision should ensure on a continuous basis. The investigators supervised the data collection and verified the validity, accuracy and completeness of data through on-the-spot checking. Regular feedbacks were given to the enumerators for maintaining an acceptable level of data quality. Regarding ethical issues, all respondents were informed about the purpose of the study and their verbal consent will obtained before taking interviews. All information will be kept anonymous and confidential. Data management and analysis: The questionnaires were checked in the field by the supervisors for any inconsistency and incompleteness.

\section{Formulation of rice-based energy dense bakery food items}

Our population target is children at age of 4 to 12 years and their expected weight ranges from 16.71 to $34.38 \mathrm{~kg}$ for boys and 16.0 to $37.0 \mathrm{~kg}$ for girls at Bangladesh population standard including both sexes [7]. We have formulated our rice-based products with several ingredients including Rice flour (Selective), sugar, skimmed milk, egg, vanilla essence, grinded sagu powder and extract of aloe vera as lubricating agent, butter, yeast powder, Rice Bran Oil (RBO) and vegetable edible oil. The metabolizeable energy values of all 
formulated foods ingredient was given in kilocalories (kcal). The energy values have to be calculated based on protein, fat, available carbohydrates and fibre values and by applying the energy conversion factors such as $\mathrm{kcal} / \mathrm{g} 4 ; 9 ; 4$ and $2 \mathrm{kcal}$ respectively. Since rice flour does not have gluten protein unlike wheat, so making dough was seeming difficult to get appropriate texture in reality. We had tried to overcome the problem with few measurements such as Unparboiled milled rice were treated for one hour soaking in water at room temperature before grinding into flour, Both low Apparent Amylose Content (AAC) and Gelatinization Temperature (GT) rice flour were mostly suitable for rice-based bakery products, Flour parameters such as Oil Absorption Capacity (OAC), Water Absorption Capacity (WAC) and forming activity etc. would be considered at flour quality selection, Sheaving flour to attain unique flour size is a necessary step and Sagu, casava and aloe vera can potentially be used as thickening, stabilizing, suspending, and binding agent.

Proximate analysis of energy dense rice-based bakery product

- Estimation of protein: Standard micro Kjeldahl procedure of AOAC [9] were used for the determination of nitrogen and crude protein were estimated by multiplying the nitrogen content by a factor 5.95 for rice flour and 6.25 for egg.

- Moisture: Moisture content were determined by AOAC method [9].

- Dietary fibre (g)/crude fibre: Dietary fiber were determined by AOAC method 2000 [10].

- Ash (g): Ash content of grain were estimated by heating the dried raw sample in a Muffle furnace at $600^{\circ} \mathrm{C}$ to burn out all organic materials for 3-5 hours till to constant weight. The inorganic residue will be quantified as the ash content by AOAC method 2000 [11].

- Estimation of Fat: Fat were extracted from the grounded rice samples with Chloroform: Methanol (2:1) solution. Fat was determined from the extract by the method of Choudhury and Juliano [12].

- Carbohydrate (g): The carbohydrate content of a sample was calculated by subtracting the percentage of other components of that sample (moisture, ash, fat, protein and fiber) from 100. Percentage of carbohydrate $=100-($ moisture + ash + fat + protein + fiber).

- Estimation of Minerals and Heavy metals: Minerals (Zn, $\mathrm{Fe}, \mathrm{Ca}$ ) and heavy metals ( $\mathrm{As}, \mathrm{Pb}, \mathrm{Ni}$ and $\mathrm{Cd}$ ) were estimated in AAS by method of the Association of Official Agricultural Chemists, AOAC, 2019 [13]. National Institute of Standards and Technology (NIST) reference material Rice flour NIST SRM 1568b SIGMA-ALDRICH, USA was used for mineral and heavy metal estimation in Atomic Absorption Spectro- photometer (AAS) [14]. Estimation of phosphorus was carried out by measuring calorimetrically the blue color formed when the ash solution was treated with ammonium molybdate and the phosphomolybdate thus formed was reduced [15].

- Blood chemistry: CBC (Complete Blood Count) including $\mathrm{Hb} \%$, TWC (Total White cell count), RBC (Red Blood Cell Count) were analyzed by automated hematology analyzer (Brand: Landmark Biomedicals). Serum levels also decline in patients with conditions associated with protein malnutrition, such as malignancy, cirrhosis, protein-losing enteropathy, and zinc deficiency. Serum Prealbumin was estimated by Human Prealbumin ELISA Kit (ab231920) [16].

Impact evaluation study on energy dense rice food product on street children

Formulated foods such as EDRC and EDRB were prepared based on the calorie gap between recommended calorie intake and actually calorie intake for the age 4 to 12 years for both sexes. Regarding impact evaluation we have divided our required samples (Total 52 samples; 32 samples for treatment: 20 for control into two groups. Treatment groups (having formulated rice-based foods for four months' time) and control group (without formulated rice-based foods). These two groups were selected using propensity score matching [17]. Test group children used to gather in an open school for spending one hour time while intaking the supplied EDRC and their activities were routinely digitally monitored. Then mean difference in different parameters were analyzed by Independent $t$ test and paired t test in R Version 4.02 and we were able to come to a decision whether this special supplementary diet can improve present status of the street children or not.

\section{Results and Discussion}

Baseline survey on daily Calorie intake of street children in capital city, Dhaka

A total of 384 street children were subjected to interview for baseline survey on their present Calorie (kcal) intake per day. RDI for 4 - 12 yrs. Boys and Girls are ranged from 1303 - $2200 \mathrm{kcal}$ and 1202 - $2070 \mathrm{kcal}$ respectively. Our survey data revealed that 27$59 \%$ gap or deficiency of RDI prevailed in Boys population (Table 1) and 28 - 56\% gap of RDI for Girls population (Table 2). We have predicted while our ongoing baseline survey that if we can produce to supplement $500 \mathrm{kcal}$ by $100 \mathrm{~g}$ serving once a day then minimization of RDI gap can be $38-100 \%$ and $56-100 \%$ for Boys and Girls of 4-12 yrs. Respectively (Table 1 and 2). Z-score can identify and pinpoint deterioration in weight and height of children in reference to the children of same age and sex. Z-score is more accurate and reliable way of presenting prevalence data in population level sur- 
veys. In $\mathrm{Z}$ score analysis considering Weight for Age condition, less than $-2 \sigma$ score is classified as underweight, score between- $2 \sigma$ to $-3 \sigma$ classified as moderate underweight and more than $-3 \sigma$ score classified as severe underweight. On the other hand, in $\mathrm{Z}$ score analysis considering Height for Age condition, less than $-2 \sigma$ score is classified as stunting, score between- $2 \sigma$ to $-3 \sigma$ classified as moderate stunting and more than $-3 \sigma$ score classified as severe stunt- ing [18]. Our data revealed that both boys and girls for Weight for Age and Height for Age were less than $-2 \sigma$ score which classified as underweight and stunting population of 4-12 yrs. in our current baseline survey for street children respectively (Figure 1 and 2). In our statistical data analysis, less than $5^{\text {th }}$ percentile were used to define shortness and low weight-for-length of our target population for both Boys and Girls of 4-12 yrs.

\begin{tabular}{|c|c|c|c|c|c|c|c|c|c|c|c|}
\hline \multirow{5}{*}{ Male } & Age & $\begin{array}{c}\text { RDI } \\
\text { In } \\
\text { Kcal }\end{array}$ & $\begin{array}{c}\text { Observed } \\
\text { Data } \\
\text { Ranges } \\
\text { in Kcal }\end{array}$ & $\begin{array}{c}\text { Observed } \\
\text { Average } \\
\text { Data } \\
\text { in Kcal }\end{array}$ & $\begin{array}{c}\text { RDI } \\
\% \\
\text { intake }\end{array}$ & $\begin{array}{c}\text { Gap } \\
\text { In } \\
\text { Kcal }\end{array}$ & $\begin{array}{l}\text { Gap } \\
\% \text { of } \\
\text { RDI }\end{array}$ & $\begin{array}{c}\text { EDRB } \\
\text { Kcal } \\
\text { per100g } \\
\text { serving }\end{array}$ & $\begin{array}{c}\text { EDRB } \\
\text { Provide } \\
\text { RDI\% }\end{array}$ & $\begin{array}{c}\text { Gap } \\
\text { \% of } \\
\text { RDI \% } \\
\text { Remain }\end{array}$ & $\begin{array}{c}\text { Predicted } \\
\text { Kcal gap } \\
\text { Minimization } \\
\text { of RDI\% }\end{array}$ \\
\hline & $4(n=13)$ & 1303 & $600-1100$ & 955 & 73 & 348 & 27 & 500 & 38 & -11 & 100 \\
\hline & $5(n=11)$ & 1362 & $630-1210$ & 865 & 63 & 497 & 37 & 500 & 37 & 0 & 100 \\
\hline & $6(n=14)$ & 1403 & $670-1180$ & 852 & 61 & 551 & 39 & 500 & 36 & 3 & 92 \\
\hline & $7(n=21)$ & 1507 & $720-1187$ & 994 & 66 & 513 & 34 & 500 & 33 & 1 & 97 \\
\hline \multirow{5}{*}{$\begin{array}{l}n= \\
243\end{array}$} & $8(n=20)$ & 1624 & $620-1170$ & 919 & 57 & 705 & 43 & 500 & 30 & 13 & 70 \\
\hline & $9(n=35)$ & 1750 & $620-1250$ & 865 & 49 & 885 & 51 & 500 & 28 & 23 & 55 \\
\hline & $10(\mathrm{n}=32)$ & 1890 & $670-1300$ & 877 & 46 & 1013 & 54 & 500 & 26 & 28 & 48 \\
\hline & $11(n=40)$ & 2038 & $620-1400$ & 866 & 42 & 1172 & 58 & 500 & 24 & 34 & 41 \\
\hline & $12(\mathrm{n}=57)$ & 2200 & $650-1280$ & 893 & 41 & 1307 & 59 & 500 & 23 & 36 & 38 \\
\hline & \multicolumn{11}{|c|}{ EDRB: Energy dense rice biscuit; ED: Energy Density: RDI: Recommended dietary intake } \\
\hline
\end{tabular}

Table 1: Baseline survey on daily dietary intake of street children (age 4-12) for boys.

\begin{tabular}{|c|c|c|c|c|c|c|c|c|c|c|c|}
\hline \multirow{5}{*}{ Female } & Age & $\begin{array}{c}\text { RDI } \\
\text { in } \\
\text { Kcal }\end{array}$ & $\begin{array}{l}\text { Observed } \\
\text { Data } \\
\text { ranges in } \\
\text { Kcal }\end{array}$ & $\begin{array}{c}\text { Observed } \\
\text { (Average) } \\
\text { data } \\
\text { in Kcal }\end{array}$ & $\begin{array}{c}\text { RDI } \\
\% \\
\text { intake }\end{array}$ & $\begin{array}{c}\text { Gap } \\
\text { In } \\
\text { Kcal }\end{array}$ & $\begin{array}{c}\text { Gap } \\
\% \text { of } \\
\text { RDI }\end{array}$ & $\begin{array}{c}\text { EDRB/EDRC } \\
\text { Kcal } \\
\text { per100g } \\
\text { serving }\end{array}$ & $\begin{array}{c}\text { EDRB/ } \\
\text { EDRC } \\
\text { provide } \\
\text { RDI\% }\end{array}$ & $\begin{array}{c}\text { Gap \% } \\
\text { of } \\
\text { RDI\% } \\
\text { Remain }\end{array}$ & $\begin{array}{l}\text { Predicted Kcal } \\
\text { gap } \\
\text { minimization } \\
\text { of RDI\% }\end{array}$ \\
\hline & $4(n=12)$ & 1202 & $625-1110$ & 898 & 72 & 346 & 28 & 500 & 41 & -14 & 100 \\
\hline & $5(\mathrm{n}=19)$ & 1244 & $700-1300$ & 850 & 68 & 352 & 32 & 500 & 41 & -14 & 100 \\
\hline & $6(n=11)$ & 1300 & $658-1020$ & 769 & 59 & 531 & 41 & 500 & 38 & 3 & 93 \\
\hline & $7(n=28)$ & 1403 & $620-1180$ & 884 & 63 & 519 & 35 & 500 & 37 & -2 & 100 \\
\hline \multirow{5}{*}{$n=141$} & $8(n=11)$ & 1502 & $820-1210$ & 1002 & 67 & 500 & 33 & 500 & 33 & 0 & 100 \\
\hline & $9(n=13)$ & 1638 & $672-970$ & 767 & 47 & 871 & 53 & 500 & 30 & 23 & 56 \\
\hline & $10(\mathrm{n}=15)$ & 1777 & $670-1170$ & 931 & 52 & 846 & 48 & 500 & 28 & 29 & 60 \\
\hline & $11(\mathrm{n}=21)$ & 1942 & $650-1025$ & 863 & 44 & 1079 & 56 & 500 & 26 & 30 & 54 \\
\hline & $12(\mathrm{n}=11)$ & 2070 & $850-1270$ & 930 & 45 & 1140 & 55 & 500 & 24 & 31 & 56 \\
\hline & \multicolumn{11}{|c|}{ EDRB: Energy dense rice biscuit; ED: Energy Density: RDI: Recommended dietary intake } \\
\hline
\end{tabular}

Table 2: Baseline survey on daily dietary intake of street children (age 4-12) for girls. 


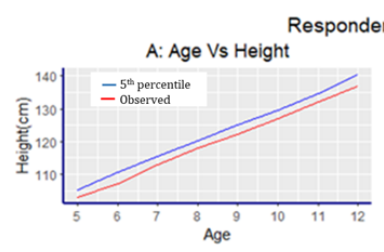

Respondents (Boys)
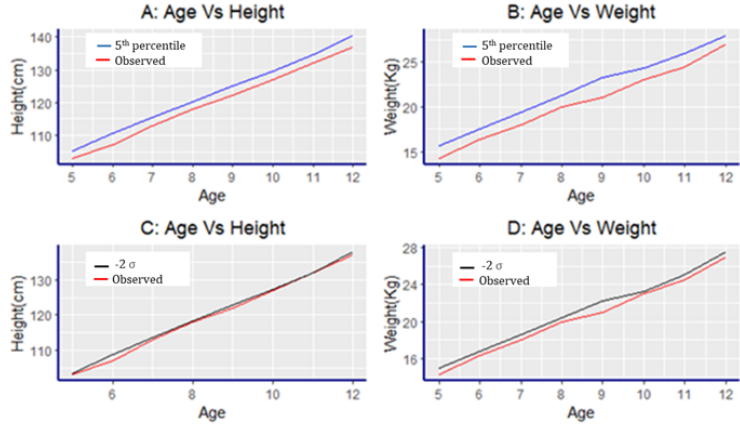

Figure 1: Percentile and Z-Score of Boy's population ( $\mathrm{n}=243)$ Height for Age and Weight for Age.

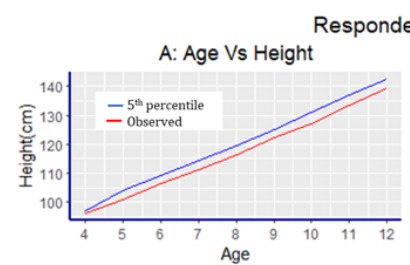

C: Age Vs Height
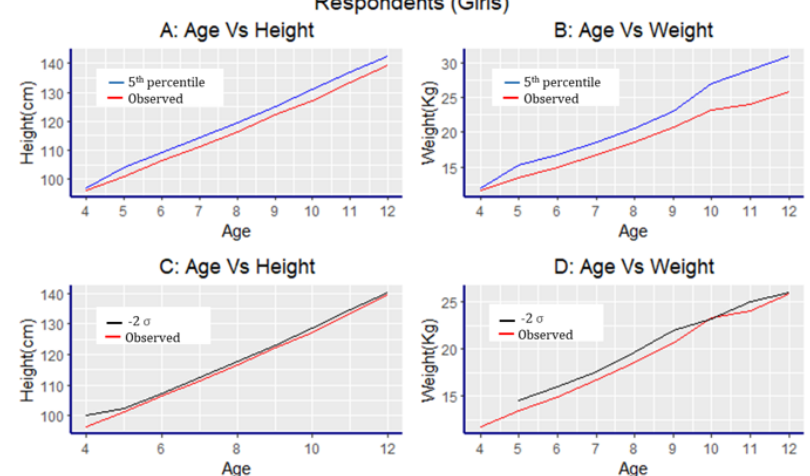

Figure 2: Percentile and Z-Score of Boy's population ( $\mathrm{n}=141$ ) Height for Age and Weight for Age.

Formulation of low cost, nutritious and safe rice-based food

Since rice flour does not have gluten protein unlike wheat, so making dough or batter was seemed difficult to get appropriate texture in reality. We had tried to overcome the problem with few measurements such as follows, i. Un-parboiled milled rice was treated for one hour soaking in water at room temperature before grinding into flour, ii. Parboiled rice was used for rice-based bakery products (Figure 3A-3C) subjected to low Glycemic rice products only and in other case un-parboiled milled rice will be uses for bakery purposes, iii, Both low apparent amylose content (AAC) and gelatinization temperature (GT) rice flour were considered suitable parameters for rice-based bakery products., iv, Rice flour parameters such as oil absorption capacity (OAC), water absorption capacity (WAC) and forming activity etc. were also considered at flour quality selection, v. Sheaving flour to attain unique flour size was a necessary step and sagu, casava and aloevera can potentially be used as thickening, stabilizing, suspending, and binding agent. Ingredients of ERDB and EDRC were rice flour, sugar, skimmed milk, egg, vanilla essence, grinded sagu powder as lubricating agent, butter and RBO. Bangladesh Standards and Testing Institute (BSTI) is the prime standardizing authority in Bangladesh for food quality control. Since BSTI did not have currently rice standards but wheat flour only so, we formulated rice-based biscuit with reference of high protein wheat biscuit prescribed by BSTI and tried to fortified fat content which formulated first time in Bangladesh. Our energy dense rice biscuit (EDRB) and cake (EDRC) had energy density ranges from 5.0-5.15 which means per $100 \mathrm{~g}$ serving EDRB and EDRC can generate 515 and $500 \mathrm{kcal}$ respectively (Table 3 and 4). According to BSTI minerals such as $\mathrm{Zn}, \mathrm{Fe}, \mathrm{Ca}$ Phos. and heavy metals such as $\mathrm{As}, \mathrm{Pb}, \mathrm{Cd}$ and $\mathrm{Ni}$ were supposed to be quantify and check the presence in rice-based products respectively. We quantified all required minerals and checked the presence of heavy metals in our products (Table 3 and 4). For our products we used, $57-59 \%$ carbohydrate from rice flour and sagu powder together, then 25 to $27 \%$ fat from Rice bran oil and butter together, then 10 to $10.6 \%$ protein from milk, egg together (Table 3 and 4). Proportionate use of sagu powder mixed with rice flour gave good bakery texture for rice biscuit and cake as sagu powder served as binding agent. Rice-based formulated diets for children with moderate to acute malnutrition must have some important characteristics including high content of micronutrients, especially growth (type II) nutrients, high energy density (defined as the ratio of energy per weight of food), adequate high protein and fat content, low content of anti-nutrients, low risk of contamination, acceptable taste and texture, culturally acceptable, easy to prepare, affordable and available. High energy density rice is most desirable for children with wasting, as they have an increased energy need for catch-up growth. The most important factor influencing energy density is the fat content, as the energy density of fat $\left(9 \mathrm{kcalg}^{-1}\right)$ according to the Atwater factors is more than double that of protein and carbohydrate $\left(4 \mathrm{kcalg}^{-1}\right)$. A major factor constraining accessibility of poor is price volatility. As the poor spend a relatively larger proportion of their income in basic stables, a sudden spike in price is equivalent to reduction in their real incomes. This will constrain their ability to acquire adequate quantity of staples. Considering this fact into account, our formulated products will not cost more than $\$ 0.10$ USD or 8.5 BDT (Bangladeshi Taka) for 100g serving which supposed to be cost effective.

Impact evaluation study of rice based formulated food on street children

Our population target is children at age of 4 to 12 years and their expected weight ranges from 16.71 to $34.38 \mathrm{~kg}$ for boys and 16.0 to 


\begin{tabular}{|l|l|c|c|c|c|}
\hline $\begin{array}{c}\text { Proximate } \\
\text { components }\end{array}$ & $\begin{array}{c}\text { Amount } \\
\text { in g }\end{array}$ & Kcal $^{-1} \mathbf{g}$ & $\begin{array}{c}\text { Estimated } \\
\text { Kcal }\end{array}$ & Minerals & $\begin{array}{c}\text { Amount } \\
-\mathbf{1 0 0 g}\end{array}$ \\
\hline Carbohydrate & 57 & 4 & 228 & $\mathrm{Zn}$ & $2.50 \mathrm{mg}$ \\
\hline Fat & 27 & 9 & 243 & $\mathrm{Fe}$ & $0.71 \mathrm{mg}$ \\
\hline Protein & 10.6 & 4 & 42.4 & $\mathrm{Ca}$ & $3.80 \mathrm{mg}$ \\
\hline Dietary Fiber & 1 & 2 & 2 & Phos & $125 \mathrm{mg}$ \\
\hline Ash & 0.8 & 0 & 0 & $\mathrm{As}$ & $<0.1 \mathrm{ppm}$ \\
\hline Moisture & 3.6 & 0 & 0 & $\mathrm{~Pb}$ & $<0.1 \mathrm{ppm}$ \\
\hline Net weight & 100 & - & 515.4 & $\mathrm{Cd}$ & $<0.1 \mathrm{ppm}$ \\
\hline $\begin{array}{l}\text { Energy Density } \\
\text { (ED) }\end{array}$ & 5.2 & - & $515 \mathrm{Kcal}$ & $\mathrm{Ni}$ & $<0.1 \mathrm{ppm}$ \\
\hline
\end{tabular}

Table 3: Proximate analysis of EDRB (Energy dense rice biscuit).

\begin{tabular}{|l|c|c|c|c|c|}
\hline $\begin{array}{c}\text { Proximate } \\
\text { components }\end{array}$ & $\begin{array}{c}\text { Amount } \\
\text { in g }\end{array}$ & Kcal $^{-1} \mathbf{g}$ & $\begin{array}{c}\text { Estimated } \\
\text { Kcal }\end{array}$ & Minerals & $\begin{array}{c}\text { Amount } \\
\mathbf{- 1}^{-1} \mathbf{1 0 0 g}\end{array}$ \\
\hline Carbohydrate & 59 & 4 & 236 & $\mathrm{Zn}$ & $2.30 \mathrm{mg}$ \\
\hline Fat & 25 & 9 & 225 & $\mathrm{Fe}$ & $0.51 \mathrm{mg}$ \\
\hline Protein & 10 & 4 & 40 & $\mathrm{Ca}$ & $3.60 \mathrm{mg}$ \\
\hline Dietary Fiber & 0.5 & 2 & 1 & Phos & $115 \mathrm{mg}$ \\
\hline Ash & 0.5 & 0 & 0 & $\mathrm{As}$ & $<0.1 \mathrm{ppm}$ \\
\hline Moisture & 5.0 & 0 & 0 & $\mathrm{~Pb}$ & $<0.1 \mathrm{ppm}$ \\
\hline Net weight & 100 & - & 502 & $\mathrm{Cd}$ & $<0.1 \mathrm{ppm}$ \\
\hline $\begin{array}{l}\text { Energy } \\
\text { Density (ED) }\end{array}$ & 5.02 & - & $502 \mathrm{Kcal}$ & $\mathrm{Ni}$ & $<0.1 \mathrm{ppm}$ \\
\hline
\end{tabular}

Table 4: Proximate analysis of EDRC (Energy dense rice cake).

$37.0 \mathrm{~kg}$ for girls at Bangladesh population standard including both sexes (from 4 years to 12 yrs. of age) ranges from 1303-2200 and $1202-2070 \mathrm{kcal} /$ day according to FAO for Bangladeshi population $[7,8]$ which requires 78 to $64 \mathrm{kcal} / \mathrm{kg} /$ day for boys and 75 to 56 $\mathrm{kcal} / \mathrm{kg} /$ day for girls respectively (from 4 years to $12 \mathrm{yrs}$. of age) as FAO reference [8]. A total of 52 respondents including 32 testing and 35 controls samples of both sexes were keep in impact study of formulated food (Rice based cake or biscuit) on street children. We have set up a free one-hour schooling at our project field at Uttara near the Turag river side. where informal education was given for 4 months. We tried to monitor that the serving amount of $100 \mathrm{~g}$ equivalent rice cake were properly intake by selected 32 volunteers or respondents at daily basis. In order to monitor our feeding activities, we have to set up this type of field school temporarily. Blood samples were taken at day 0 as initial and $100 \mathrm{~g}$ of serving per day formulated food (Rice based cake or biscuit) were given to 32 testing samples every day for 4 months' time without hampering their normal food intake. On the other-hand controls were not feed the similar amount of $100 \mathrm{~g}$ of serving per day formulated food (Rice

based cake or biscuit) but keeping them on their usual intake of food. Control group for 20 street children were subjected to draw the blood samples as initial too. At the end of 4 months' time blood samples from both samples and controls were taken for comparison of blood parameters specially CBC (Complete Blood Count), Hemoglobin, CRP and Prealbumin. Blood parameters related to malnutrition such as CBC (Complete Blood Count), Hemoglobin, CRP and Prealbumin were collected at both the starting and the end time of the impact survey of selected 52 respondents including testing and control samples. In impact study at day 0, fifty-two (52) respondent including 32 testing samples and 20 control samples were subjected to draw blood samples for estimating several malnutrition related blood parameters such as CBC (Complete Blood Count), Hemoglobin, CRP and Prealbumin were examined. These respondents also subjected for their daily Calorie intake baseline survey at day 0 . From that onwards, a supplementary energy dense rice cake (EDRC) having ED 5.0 was distributed among 32 testing samples for 120 days or 4 months duration without interfering their regular food intake. Since testing samples were given $500 \mathrm{kcal}$ supplements so at the end of the 4-month time their daily energy intake found higher than control group which reflects in overall improvement in blood parameters such as increased $\mathrm{Hb} \%$, Total White cell count (TWC), Red blood cell (RBC), Prealbumin and decreased CRP protein. Our data revealed that the Deficiency of RDI\% in our population street children for respective age group were improved by $70-100 \%$ at day 120 for taking supplementary rice-based food once a day (Table 5). Before starting the impact study, our target samplings for both control $(n=20)$ and treatment groups $(\mathrm{n}=32)$ were checked statistically by Independent $\mathrm{t}$ test at day $0(\alpha=0.05)$ since there was no mean difference between control and treatment group at day 0 for hemoglobin, TWC, RBC, CRP and Prealbumin (Table 6). Null hypothesis for the mean differences between the before and after treatment at day 120 for hemoglobin, TWC, RBC, CRP and Prealbumin were found significant by Paired t test $(\alpha=0.05)$ (Table 7). Finally, Null hypothesis for measuring mean difference between control and treatment group at day 120 for several blood parameters such as hemoglobin, TWC, RBC, CRP and Prealbumin were found significant by Independent $t$ test $\alpha=$ 0.05 (Table 8). All statistcal analysis clearly indicate that there was a significant improvement in treatment or testing group compared to control grooup. EDRC can potentially be used in school feeding nutrition program and disaster mangement including refugee crisis, flood or cyclone related emergency relief operation program to mitigate malnutrition and emergency response of energy dense dry food as suppliments. Thus we can attain SDG goal 2.0 (Zero hunger) specially 2.1 goal which deals with a vision to end hunger and ensure access by all people, in particular the poor and people in vulnerable situations, including infants, to safe, nutritious and sufficient food all year round. 


\begin{tabular}{|c|c|c|c|c|c|c|c|c|c|}
\hline Name & Age & Gender & $\begin{array}{c}\text { Daily Energy } \\
\text { at } 0 \text { day } \\
\text { (Observed) } \\
\text { kcal/day }\end{array}$ & $\begin{array}{l}\text { Age based } \\
\text { RDI } \\
\text { kcal/day }\end{array}$ & $\begin{array}{c}\text { Deficiency } \\
\%\end{array}$ & $\begin{array}{c}\text { EDRC } \\
\text { kcal/day }\end{array}$ & $\begin{array}{c}\text { Daily Energy at } \\
120 \text { day } \\
\text { (Observed) kcal/ } \\
\text { day }\end{array}$ & Deficiency \% & $\begin{array}{c}\text { Deficiency } \\
\text { status } \\
\text { improved }\end{array}$ \\
\hline Rohita & 5 & Female & 880 & 1202 & 26.8 & 500.0 & 1380 & -14.8 & 100 \\
\hline Hasan & 5 & Male & 1160 & 1362 & 14.8 & 500.0 & 1660 & -21.9 & 100 \\
\hline Siam & 6 & Male & 1180 & 1403 & 15.9 & 500.0 & 1680 & -19.7 & 100 \\
\hline Samia & 6 & Female & 1290 & 1300 & 0.8 & 500.0 & 1790 & -37.7 & 100 \\
\hline Lamia & 6 & Female & 1210 & 1300 & 6.9 & 500.0 & 1710 & -31.5 & 100 \\
\hline Fahima & 6 & Female & 1240 & 1300 & 4.6 & 500.0 & 1740 & -33.8 & 100 \\
\hline Mim & 6 & Female & 1230 & 1300 & 5.4 & 500.0 & 1730 & -33.1 & 100 \\
\hline Shohid & 6 & male & 1130 & 1403 & 19.5 & 500.0 & 1630 & -16.2 & 100 \\
\hline Itila Akter & 6 & Female & 1030 & 1300 & 20.8 & 500.0 & 1530 & -17.7 & 100 \\
\hline Yeasin & 7 & Male & 1280 & 1507 & 15.1 & 500.0 & 1780 & -18.1 & 100 \\
\hline Sakib & 7 & Male & 1280 & 1507 & 15.1 & 500.0 & 1780 & -18.1 & 100 \\
\hline Jhuma & 8 & Female & 1280 & 1502 & 14.8 & 500.0 & 1780 & -18.5 & 100 \\
\hline Tinni Akter & 8 & Female & 1080 & 1502 & 28.1 & 500.0 & 1580 & -5.2 & 100 \\
\hline Mahfuj & 8 & Male & 1340 & 1624 & 17.5 & 500.0 & 1840 & -13.3 & 100 \\
\hline Susmita & 8 & Female & 1230 & 1502 & 18.1 & 500.0 & 1730 & -15.2 & 100 \\
\hline Maria & 8 & Female & 1230 & 1502 & 18.1 & 500.0 & 1730 & -15.2 & 100 \\
\hline $\begin{array}{l}\text { Mehedi } \\
\text { Hasan }\end{array}$ & 9 & Male & 1080 & 1750 & 38.3 & 500.0 & 1580 & 9.7 & 92.3 \\
\hline $\begin{array}{l}\text { Irin Akter } \\
\text { Shila }\end{array}$ & 9 & Female & 1340 & 1638 & 18.2 & 500.0 & 1840 & -12.3 & 100 \\
\hline Miraz & 10 & Male & 1410 & 1890 & 25.4 & 500.0 & 1910 & -1.1 & 100 \\
\hline Akash & 10 & Male & 1310 & 1890 & 30.7 & 500.0 & 1810 & 4.2 & 95.8 \\
\hline Konika & 10 & Female & 1030 & 1777 & 42.0 & 500.0 & 1530 & 13.9 & 86.1 \\
\hline Rbbi Miah & 11 & Male & 1330 & 2038 & 34.7 & 500.0 & 1830 & 10.2 & 89.8 \\
\hline Md. Yakub & 11 & Male & 1280 & 2038 & 37.2 & 500.0 & 1780 & 12.7 & 87.3 \\
\hline $\begin{array}{l}\text { Md. Sakib } \\
\text { Miah }\end{array}$ & 11 & Male & 930 & 2038 & 54.4 & 500.0 & 1430 & 29.8 & 70.2 \\
\hline Md. Jaman & 11 & Male & 1230 & 2038 & 39.6 & 500.0 & 1730 & 15.1 & 84.9 \\
\hline Kiran Miah & 11 & Male & 1030 & 2038 & 49.5 & 500.0 & 1530 & 24.9 & 75.1 \\
\hline Farzana & 11 & Female & 1210 & 1942 & 37.7 & 500.0 & 1710 & 11.9 & 88.1 \\
\hline Mithila & 11 & Female & 930 & 1942 & 52.1 & 500.0 & 1430 & 26.4 & 73.6 \\
\hline Sharmin & 11 & Female & 1230 & 1942 & 36.7 & 500.0 & 1730 & 10.9 & 89.1 \\
\hline Nishita & 11 & Female & 1080 & 1942 & 44.4 & 500.0 & 1580 & 18.6 & 81.4 \\
\hline $\begin{array}{l}\text { Choity } \\
\text { Akter }\end{array}$ & 11 & Female & 1130 & 1942 & 41.8 & 500.0 & 1630 & 16.1 & 83.9 \\
\hline $\begin{array}{l}\text { Fatima } \\
\text { Akter }\end{array}$ & 12 & Female & 1180 & 2070 & 43.0 & 500.0 & 1680 & 18.8 & 81.2 \\
\hline
\end{tabular}

Table 5: Impact study of EDRC on street children (age 4-12 yrs. for 14 boys and 18 girls 


\begin{tabular}{|c|c|c|c|c|}
\hline & \multicolumn{2}{|c|}{ Male } & \multicolumn{2}{|c|}{ Female } \\
\hline Null Hypothesis & $P$ value & Decision & P value & Decision \\
\hline $\begin{array}{l}\text { There is no mean } \\
\text { difference } \\
\text { between control } \\
\text { and } \\
\text { treatment group } \\
\text { at day } 0 \text { of } \\
\text { hemoglobin. }\end{array}$ & 0.6331 & Not rejected & 0.7155 & $\begin{array}{c}\text { Not } \\
\text { rejected }\end{array}$ \\
\hline TWC & 0.7534 & Not rejected & 0.7939 & $\begin{array}{c}\text { Not } \\
\text { rejected }\end{array}$ \\
\hline CRP & 0.6779 & Not rejected & 0.6197 & $\begin{array}{c}\text { Not } \\
\text { rejected }\end{array}$ \\
\hline Prealbumin & 0.899 & Not rejected & 0.6777 & $\begin{array}{c}\text { Not } \\
\text { rejected }\end{array}$ \\
\hline
\end{tabular}

Table 6: Null hypothesis for selecting samples for control and treatment group at day 0 .

\section{Conclusion}

A baseline survey on street children was conducted to generate awareness for malnutrition scenario in capital city of Bangladesh. Based on the Calorie gap estimated from baseline survey, low cost, nutritionally balanced and safe rice-based bakery food items were formulated for Bangladeshi population especially street children with malnutrition. Finally impact study on rice-based bakery items specially energy dense rice cake was found an effective supplementary diet for improvement of blood parameters in addressing malnutrition in street children. On the top of these research findings, rice-based food items seem have immense potential in Bangladesh, since these rice-based products usually utilize a relatively small amount of carbohydrate in preparation so it will help to reduce rice intake gradually. Rice based energy dense bakery products can also be utilized in school feeding nutritional program and disaster management related program in Bangladesh.

\begin{tabular}{|l|c|c|c|c|}
\hline \multicolumn{1}{|c|}{ Null Hypothesis } & P value & Decision & P value & Decision \\
\hline $\begin{array}{l}\text { The mean differences between the before and after } \\
\text { treatment of Hemoglobin readings equals 0. }\end{array}$ & $7.781 \mathrm{e}-05$ & $\begin{array}{c}\text { Reject the null } \\
\text { hypothesis }\end{array}$ & $5.059 \mathrm{e}-07$ & $\begin{array}{c}\text { Reject the null } \\
\text { hypothesis }\end{array}$ \\
\hline $\begin{array}{l}\text { The mean of differences between the before and after } \\
\text { treatment of CRP readings equals 0. }\end{array}$ & 0.0260 & $\begin{array}{c}\text { Reject the null } \\
\text { hypothesis }\end{array}$ & 0.0007 & $\begin{array}{c}\text { Reject the null } \\
\text { hypothesis }\end{array}$ \\
\hline $\begin{array}{l}\text { The mean of differences between the before and after } \\
\text { treatment of Prealbumin } \\
\text { readings equals 0. }\end{array}$ & $5.34 \mathrm{e}-08$ & $\begin{array}{c}\text { Reject the null } \\
\text { hypothesis }\end{array}$ & $1.497 \mathrm{e}-08$ & $\begin{array}{c}\text { Reject the null } \\
\text { hypothesis }\end{array}$ \\
\hline $\begin{array}{l}\text { The mean of differences between the before and after } \\
\text { treatment of TWC readings equals 0. }\end{array}$ & 0.0016 & $\begin{array}{c}\text { Reject the null } \\
\text { hypothesis }\end{array}$ & 0.0007 & $\begin{array}{c}\text { Reject the null } \\
\text { hypothesis }\end{array}$ \\
\hline Paired t test $(\alpha=0.05)$. & & &
\end{tabular}

Table 7: Null hypothesis for the mean differences between the before and after treatment at day 120.

\begin{tabular}{|c|c|c|c|c|}
\hline \multirow{2}{*}{ Null Hypothesis } & \multicolumn{2}{|c|}{ Male } & \multicolumn{2}{|r|}{ Female } \\
\hline & $P$ value & Decision & $P$ value & Decision \\
\hline $\begin{array}{l}\text { There is no mean difference between control and } \\
\text { treatment group at } 120 \text { days of Hemoglobin. }\end{array}$ & 0.0004 & $\begin{array}{l}\text { Reject the null } \\
\text { hypothesis }\end{array}$ & 0.0307 & Reject the null hypothesis \\
\hline $\begin{array}{l}\text { There is no mean difference between control and } \\
\text { treatment group at } 120 \text { days of TWC. }\end{array}$ & 0.0411 & $\begin{array}{l}\text { Reject the null } \\
\text { hypothesis }\end{array}$ & 0.0480 & Reject the null hypothesis \\
\hline $\begin{array}{l}\text { There is no mean difference between control and } \\
\text { treatment group at } 120 \text { days of CRP. }\end{array}$ & 0.0078 & $\begin{array}{l}\text { Reject the null } \\
\text { hypothesis }\end{array}$ & 0.0003 & Reject the null hypothesis \\
\hline $\begin{array}{l}\text { There is no mean difference between control and } \\
\text { treatment group at } 120 \text { days of Prealbumin. }\end{array}$ & 0.0419 & $\begin{array}{l}\text { Reject the null } \\
\text { hypothesis }\end{array}$ & 0.0410 & Reject the null hypothesis \\
\hline nt t test at day $120(\alpha=0.05)$. & & & & \\
\hline
\end{tabular}

Table 8: Null hypothesis for measuring mean difference between for control and treatment group at day 120. 

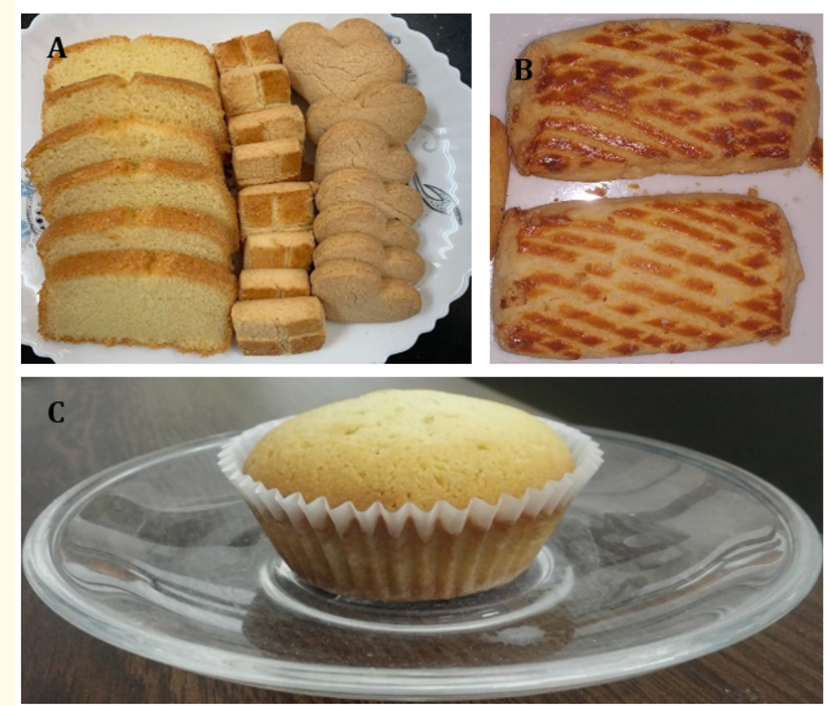

Figure 3: A. Rice based bakery products. B. Energy dense rice biscuit (EDRB). C. Energy dense rice cake (EDRC).

\section{Acknowledgements}

Authors would like to acknowledge all staffs of GQN Division of BRRI, students of department of EAST West University for their support in conducting baseline survey and climate school for assisting impact study activities. Special acknowledgement to PIUBARC, NATP-2, Farmgate, Dhaka authority for funding this research activities.

\section{Conflict of Interest}

Authors declare that there is no any conflict of interest.

\section{Bibliography}

1. Aparajeyo Bangladesh presented a paper on street children of Bangladesh in a Consortium for Street Children. Colombo, Srilanka. A Civil Society Forum for South Asia on Promoting and Protecting the Rights of Street Children Consortium for Street Children (2001).

2. Mohammad AB. "Street children". The Daily Star (2009).

3. Mohammed NAR and Mahfuja S. "Street children in Bangladesh: A life of uncertainty". Editorial, The Independent, 6 February (2016).

4. Hakim MA and Rahman A. "Health and Nutritional Condition of Street Children of Dhaka City: An Empirical Study in Bangladesh". Science Journal of Public Health 4 (2016): 6-9.
5. Syed MA., et al. "Lives and Livelihoods on the Streets of Dhaka City: Findings from a Population-based Exploratory Survey". BRAC Working Paper No. 19, March (2011).

6. Saikia D and Deka SC. "Cereals: from staple food to nutraceuticals”. International Food Research Journal 18 (2011): 21-30.

7. FAO. "Human energy requirements. Report of a Joint FAO/ WHO/UNU Expert Consultation". FAO Food and Nutrition Technical Report series 1 (2004), United Nations University, Rome.

8. “Desirable Dietary Pattern for Bangladesh” (2013).

9. Official Kjeldahl procedure for grains (979.09) protein estimation of AOAC (2000).

10. Official procedure for Dietary fiber (985.29)estimation of AOAC method (2000).

11. Official procedure for Ash (942.05) estimation of AOAC (2000).

12. Choudhury NH and Juliano BO. "Effect of amylase content on the lipids of mature rice grain". Phytochemistry 19 (1980): 1385.

13. Official procedure of mineral estimations ( $\mathrm{Zn}, \mathrm{Fe}, \mathrm{Ca}, \mathrm{Mn}$ and $\mathrm{Mg}$ ) of Association of Official Agricultural Chemists (AOAC, 2019, 21st edition).

14. National Institute of Standards and Technology (NIST) reference material Rice flour NIST SRM 1568b SIGMA-ALDRICH, USA.

15. Yoshida SD., et al. "Laboratory Manual for Physiological Studies of Rice”. IRRI, Los Banos, Philippines (1976): 17-18.

16. Human Prealbumin ELISA Kit (ab231920).

17. Shahidur R., et al. "Handbook on impact evaluation quantitative methods and practices". 52099, 2010, The International Bank for Reconstruction and Development, The World Bank (2010).

18. Centers for disease control and prevention (CDC). "Healthy Weight, Nutrition, and Physical Activity".

Volume 5 Issue 7 July 2021

(C) All rights are reserved by Habibul Bari Shozib., et al. 